\author{
Abstracta Iranica \\ Abstracta Iranica Revue bibliographique pour le domaine irano-aryen \\ Volume 32-33 | 2013 \\ Comptes rendus des publications de 2009-2010
}

\title{
Cyrus Alai. Special Maps of Persia 1477-1925
}

\section{Denise Aigle}

\section{OpenEdition}

\section{Journals}

\section{Édition électronique}

URL : http://journals.openedition.org/abstractairanica/40138

DOI : 10.4000/abstractairanica.40138

ISSN : 1961-960X

Éditeur :

CNRS (UMR 7528 Mondes iraniens et indiens), Éditions de l'IFRI

Édition imprimée

Date de publication : 1 décembre 2013

ISSN : 0240-8910

\section{Référence électronique}

Denise Aigle, «Cyrus Alai. Special Maps of Persia 1477-1925», Abstracta Iranica [En ligne], Volume 32-33 | 2013, document 211, mis en ligne le 01 juillet 2016, consulté le 26 septembre 2020. URL : http://journals.openedition.org/abstractairanica/40138; DOI : https://doi.org/10.4000/ abstractairanica.40138

Ce document a été généré automatiquement le 26 septembre 2020.

Tous droits réservés 


\title{
Cyrus Alai. Special Maps of Persia 1477-1925
}

\author{
Denise Aigle
}

\section{RÉFÉRENCE}

Cyrus Alai. Special Maps of Persia 1477-1925. Leyde, Brill, 2010, 466 p., liste des planches, biblio., index chronologique des légendes des cartes, index des noms de personnes et des institutions, index des toponymes.

1 En 2005, Cyrus Alai avait déjà publié chez Brill un ouvrage intitulé : General maps of Persia, 1447-1925. Cette nouvelle publication vient donc compléter la précédente en apportant une innovation par l'inclusion d'environ 105 cartes manuscrites. Les entrées pour classer les cartes sont organisées par catégories, et dans chaque sous-chapitre selon l'ordre chronologique. Le commentaire et la présentation de chaque carte sont accompagnés de la bibliographie afférente. CA a établi une "fiche-type » comportant différentes rubriques qui sont renseignées lorsque cela est possible: nom du cartographe, lieu d'édition (ou de conservation s'il s'agit d'une carte manuscrite), date, titre, langue, dimensions, échelle, origine, etc. Le livre est découpé en neuf chapitres : cartes historiques, des districts, de la mer Caspienne et de ses rivages, du golfe Persique, des frontières, des routes, des sites historiques (Ardabil, Bampur, Bisotun, etc.), des communications, transports et tribus, et, enfin, cartes topographiques et géologiques. Les documents reproduits et les commentaires font la richesse de ce magnifique ouvrage. Il intéressera non seulement les géographes, mais aussi les historiens, les archéologues, les sociologues et même les linguistes. 


\section{AUTEURS}

DENISE AIGLE

EPHE, Paris 